\title{
Pengembangan Model Pelayanan Kantor Desa terhadap Masyarakat Berbasis Mobile Computing
}

\author{
Triyani Arita Fitri ${ }^{1}$, Torkis Nasution ${ }^{2}$, Herwin $^{3}$ \\ 1,2,3 Sekolah Tinggi Manajemen Informatik dan Komputer Amik Riau \\ e-mail: triyaniaritafitri@stmik-amik-riau.ac.id, torkisnasution@stmik-amik-riau.ac.id, \\ herwin@stmik-amik-riau.ac.id
}

\begin{abstract}
Abstrak-Desa sebagai pusat pelayanan pemerintah terhadap masyarakat pada jenjang terbawah menjadi fokus pengembangan utama dalam agenda Pemerintah. Melalui penelitian ini dikembangkan sistem adminstrasi pelayanan masyarakat secara online berbasiskan open source dengan pendekatan cloud computing, dalam melakukan administrasi kependudukan, pindah, izin usaha, izin mendirikan bangunan serta penerbitan surat dengan kemudahan dan waktu yang efisien. Metode yang digunakan adalah studi literature berkaitan dengan teknologi cloud computing, survei dan pengumpulan data perancangan infrasruktur teknologi informasi yang dapat diterapkan pada pelayanan masyarakat secara online, analisis data hasil survei terhadap kondisi nyata di beberapa pusat layanan masyarakat khususnya desa di Kabupaten Kampar, dan terakhir membuat model pelayanan masyarakat secara online dari desa seperti kartu keluarga, pindah serta melapor secara online. Hasilnya adalah sistem aplikasi administrasi pelayanan masyarakat di desa berbasis web dengan memanfaatkan teknologi cloud computing serta arsitektur pengembangan yang modular dan dinamis. Model aplikasi ini juga memadukan keunggulan aplikasi berpola open-source dengan desain sistem fleksibel untuk kebutuhan implementasi dan pengembangan, serta dukungan mobile device untuk meningkatkan kualitas pelayanan terhadap masyarakat. Struktur jaringan berbasis web memungkinkan untuk online tidak hanya antar desa dengan masyarakat tetapi juga desa dengan kecamatan serta dapat diakses kapan saja, di mana saja, menggunakan perangkat bergerak. Pengembangan model aplikasi juga didasarkan pada fungsi proses bisnis dan proses administrasi desa yang ada di peraturan pemeringah Indonesia. Setiap model juga diharapkan dapat diintegrasikan untuk mengoptimalkan efisiensi dan telah coba disesuaikan dengan sistem pelayanan masyarakat.
\end{abstract}

Kata kunci---cloud computing, desa, pengembangan model, mobile computing, open source

\section{PENDAHULUAN}

$\mathrm{T}$ eknologi informasi dan komunikasi sangat bermanfaat dalam mendukung proses bisnis dalam bentuk manajemen data, informasi, fakta, distribusi, serta pengetahuan. Bagi instansi pemerintah di Kabupaten, Kecamatan, Desa, maupun di tingkat RW dan RT, satu diantara pendukung layanan terhadap masyarakat adalah dengan menyediakan aplikasi administrasi pelayanan masyarakat secara langsung. Teknologi cloud computing merupakan solusi yang tepat dalam memanfaatkan teknologi komputer dengan pengembangan berbasis internet sebagaimana di sebutkan dalam I Putu Agus
Eka Pratama [06], yang memungkinkan pelanggan menyewa dan memanfaatkan layanan teknologi informasi dan komunikasi dengan pengelolaan infrastuktur, platform maupun aplikasi dilakukan oleh provider, tanpa ada investasi di sisi pelanggan, sehingga memudahkan akses dan secara keseluruhan memberikan kesederhanaan dan efisiensi baik dari sisi pemberi layanan maupun dari sisi masyarakat. Cloud computing merupakan sebuah transformasi dalam bentuk peningkatan produktifitas sistem dan entitas pengguna di masa depan. Cloud computing adalah terobosan berikutnya yang ada di era Internet atau virtual komunikasi. Transformasi menuju implementasi teknologi cloud computing akan merambah seluruh aspek, perusahaan, pemerintahan, maupun perseorangan. Layanan pemerintah dalam hal ini, implmentasi e-government berbasis mobile computing, dari tingkat pusat sampai tingkat desa, juga membutuhkan dukungan teknologi yang memadai termasuk juga teknologi informasi berbasis cloud computing. Seperti halnya pengembangan e-desa, yaitu pelayanan di bidang administrasi jarak jauh. Ini berarti layanan terhadap masyarakat yang mencakup semua bentuk administrasi yang memanfaatkan media, di mana masyarakat dan aparatur desa dapat berkomunikasi jarak jauh, baik menggunakan telepon seluler, telepon rumah, internet dan sebagainya sebagain disebutkan oleh Ni Ketut Bagiastuti [02]. e-desa juga didefinisikan sebagai transfer data administrasi elektronik dari satu lokasi ke lokasi lainnya secara online. edesa bisa dikatakan sebagai alat yang dapat membantu banyak orang dengan beragam masalah administrasi. Sangat banyak manfaat yang ditawarkan dalam penggunaan e-desa, dalam Siti Maimunah., Rudianto, [03] keunggulan e-desa seperti halnya efektivitas waktu, biaya dan tenaga. Artinya, masyarakat tidak perlu untuk jauh-jauh datang ke Kantor Desa yang menghabiskan banyak waktu di perjalanan, biaya bahan bakar, dan fisik bertahan di tengah-tengah kemacetan untuk membuat permohonan izin usaha kepada petugas administrasi di Kantor Desa.

Masyarakat cukup memanfaatkan teknologi informasi seperti halnya email atau bahkan video conference dan lain sebagainya untuk mendapatkan layanan administrasi tingkat desa. Manfaat lain yang ditawarkan yaitu mengatasi penumpukan berkas permohonan, ketepatan waktu, waktu menjadi lebih efisien karena warga yang memerlukan layanan administrasi tidak selalu harus ke Kantor Desa, namun cukup mengisi formulir elektronik melalui perangkat mobile miliknya yang telah di sediakan manakala memohonkan 
layanan administrasi. Intinya, dengan penyelenggaraan administrasi berbasis elektronik, masyarakat dapat memperoleh pelayanan administrasi, bertanya, berkonsultasi, jarak jauh dengan aparatur yang bertugas, hal ini di percayai mampu untuk membantu permasalahannya. Banyaknya masalah dan tantangan dalam pelayanan administrasi desa bagi masyarakat di Indonesia, justru dapat memberikaan peluang menarik untuk melakukan pengembangan sistem e-desa yang dapat membantu pemecahan masalah tersebut. Beberapa contoh masalah misalnya adalah: belum meratanya kuantitas dan kualitas bantuan yang diberikan berupa beras, atau bantuan sosial lainnya.

Group Research Cloud Computing sudah berdiri sejak tahun 2000 memfokuskan pada penelitian dalam sistem penerapan teknologi informasi dengan mudah. Penggunaan sistem e-desa berbasis teknologi komunikasi dan informasi dalam pelayanan administrasi kepada masyarakat, yang dilakukan secara bertahap dan berkelanjutan, diharapkan secara bertahap dapat meningkatkan produktivitas masyarakat dan kepuasan layanan administrasi aparat desa. Penyelenggaraan administrasi jarak jauh merupakan aplikasi teknologi elektronika, komputer dan telekomunikasi dalam teknik penerapan administrasi, untuk melakukan layanan administrasi antara masyarakat dengan RT, masyarakat dengan RW, ataupun masyarakat dengan Aparatur Desa, guna membantu pelaksanaan administrasi pemerintahan, dengan tujuan meningkatkan kualitas administrasi manusia melalui peningkatan pelayanan kepada masyarakat. Dengan demikian, dalam sistem administrasi berbasis elektronik selalu dilakukan pemrosesan informasi, pengiriman, dan penerimaan informasi kondisi terkini dari masyarakat, serta hasilnya harus menunjang pelaksanaan prosedur pemerintahan. Seiring dengan kemajuan pesat dalam teknologi pendukungnya, dalam beberapa tahun terakhir ini, telah terjadi perkembangan yang sangat pesat dalam administrasi dan e-desa. Perkembangan yang sangat pesat dalam sistem telekomunikasi bergerak (wireless mobile telecommunication) dan sistem telekomunikasi satelit, serta tersedianya infrastruktur yang disediakan oleh berbagai penyelenggara jaringan telekomunikasi, telah memungkinkan pengembangan berbagi jenis mobile layanan desa dan manajemen tingkat desa. Kemajuan dalam teknologi pendukung, termasuk perangkat keras dan perangkat lunak komputer telah mendorong berbagai pengembangan sistem administrasi dan e-desa untuk berbagai jenis aplikasi. Sebagai suatu bidang yang bersifat multidisiplin, teknik informatika menerapkan berbagai metoda engineering dan sains dalam bidang e-government untuk memproses berbagai jenis informasi pemerintahan, guna membantu pelaksanaan prosedur administrasi agar dapat meningkatkan kualitas layanan melalui peningkatan pelayanan administrasi pada masyarakat. Bidang multidisiplin ini memerlukan kerjasama sinergis banyak bidang-bidang terkait, seperti: elektronika dan mikroelektronika, komputer, telekomunikasi, informatika, ilmu pemerintahan, antropologi, networking, bahkan bidang ekonomi, hukum, etika dan agama. Beberapa contoh informasi administrasi, adalah teks alfanumeric, sinyal, suara (narator), citra (images) yang bersifat statik atau dinamik, serta berbagai kombinasinya. Dengan jumlah desa di seluruh Indonesia lebih dari 74,000 desa, masyarakat yang bertempat tinggal di desa $46 \%$ atau 110,000,000 jiwa sumber [09]. Penelitian ini menjadi begitu penting, untuk dapat di implemen-tasikan. Penelitian ini dikembangkan dengan tujuan (competitive advantages):

1. Mendapatkan bisnis plan untuk pengembangan infrastruktur sistem administrasi pelayanan administrasi yang berbasiskan open source dengan pendekatan cloud computing yang efektif dan efisien;

2. Membuat aplikasi-aplikasi pendukung sistem pelayanan administrasi yang dapat diterapkan di Desa seperti pencatatan kependudukan dan pelaporan data masyarakat, basisdata pelayanan administrasi, konsultasi izin usaha jarak jauh dan pembelajaran bagi masyarakat dan aparatur desa dalam bentuk manajemen pengetahuan dan repository berbasiskan open source program;

3. Mendapatkan model-model pelayanan administrasi jarak jauh yang berbasiskan cloud computing seperti konsultasi administrasi, online-reporting, mobile administrasi, dan real-time monitoring kondisi masyarakat secara online;

4. Membuat rekomendasi pelayanan administrasi desa berbasiskan open source secara online yang efektif dan efisien khususnya yang dapat diaplikasikan pada Desa atau warga yang jauh dari Kantor Desa.

Manfaat yang dapat diperoleh dari penelitian ini adalah: (1) mendapatkan gambaran umum dan permasalahan yang dihadapi dalam pelayanan administrasi masyarakat di Desa dan kemungkinan pengembangan pelayanan administrasi secara online menggunakan pendekatan cloud computing; (2) tersedianya sistem aplikasi administrasi desa secara online yang dapat diterapkan di Desa sehingga dapat meningkatan pelayanan kepada masyarakat dengan investasi yang relatif rendah; (3) menjadi media pembelajaran bagi masyarakat dalam menjalankan administrasi dan pencegahannya kepada setiap lapisan masyarakat tanpa batas waktu dan tempat; (4) tersedianya acuan standard bagi instansi pemerintah ataupun swasta dalam mengembangkan aplikasi pelayanan administrasi yang berkaitan dengan layanan online, formulir elektronik, pemberitahuan secara online dan pegawai online yang handal.

\section{KAJIAN LITERATUR}

Beberapa penelitian yang pernah dilakukan terkait dengan tata kelola administrasi desa secara elektronik berbasis cloud computing, diantaranya dilakukan oleh mobile computing Siti Maimunah dan Rudianto [08], yang meneliti tentang Pelayanan Teknologi Informasi dan Komunikasi untuk Pengembangan Desa, pelayanan Teknologi Informasi akan dapat meingkatkan daya saing disamping itu, masyarakat makin aktif dan ikut berkontribusi dengan memberikan informasi yang dia miliki kepada dunia luas. Dampak lebih jauh yang bisa didapatkan adalah selain berkembangnya desa, juga menjadi dikenal oleh dunia. Secara umum penelitian berbasis administrasi desa menyimpulkan : 
1. Meningkatkan daya saing masyarakat pedesaan pada tingkat global. Penelitian ini, menyatakan masyarakat memiliki pengetahuan yang kurang (39\%), namun setelah menyelesaikan pelatihan dapat meningkat secara drastis.

2. Perlu komitement dari aparat desa, masyarakat, maupun tokoh (ulama, pemuda, agamawan) untuk menerapkan administrasi desa berbasis elektronik, hal ini di kemukakan oleh S. Bayu Wahyono [08]

Sementara penelitian cloud computing yang didasarkan pada Eko Didik Widianto [01], menyimpulkan bahwa cloud computing dapat memutus rantai hambatan dalam percepatan penetrasi infrastruktur dan layanan TIK untuk pedesaan dengan menghadirkan framework sistem TIK yang memanfaatkan teknologi cloud untuk men-dayagunakan infrastruktur dan sumber daya komputasi secara optimal. Jaringan Mesh based Community Reversed Basestation beserta skema routing multiradio multihop, load balancing dan QoS dapat menjadi acuan algoritma untuk jaminan high availability layanan dalam jaringan wirelessmesh. Framework interoperasi antar provider layanan dapat digunakan dalam sistem berba-sis cloud yang lebih luas.

Dari beberapa penelitian diatas belum ada yang melaksanakan penelitian tentang e-Desa, penelitian bidang administrasi desa masih memanfaatkan aplikasi lokal, sementara penelitian berbasis cloud computing masih bersifat normatif dan teoritis, belum di ujikan secara nyata. Hal ini dibuktikan dengan belum adanya data yang disajikan atas tingkat efisiensi dan efektifitas sistem serta tingkat acceptable oleh aparat desa dan masyarakat. Oleh karena itu penelitian ini akan meneliti tentang Analisa dan Model Implementasi Sistem cloud e-Desa untuk Pengelolaan Administrasi Desa. Penelitian yang sudah dilakukan dengan masalah yang relevan di dalam Siti Maimunah dan Rudianto [03] menjelaskan bahwa dengan adanya Pelayanan ICT di desa yang masih terisolir dapat berkembang dan mampu bersaing dalam dunia yang lebih luas. Masyarakat makin aktif dan ikut berkontribusi dengan memberikan informasi yang dia miliki kepada dunia luas. Dampak lebih jauh yang bisa dida-patkan adalah selain berkembangnya desa, juga menjadi dikenal oleh dunia. Dalam menerapkan teknologi informasi di pedesan masih kurang tersedia kerangka yang baku perlu upaya yang kuat untuk mendorong teknologi cloud computing sebagai basis pengambangan teknologi informasi, hal ini di perkuat oleh Eko Didik Widianto [01] menjelaskan bahwa Cloud Computing memutus rantai hambatan dalam percepatan penetrasi infrastruktur dan layanan TIK untuk pedesaan dengan menghadirkan framework sistem TIK yang memanfaatkan teknologi cloud untuk mendayagunakan infrastruktur dan sumber daya komputasi secara optimal. Jaringan Mesh based Community Reversed Basestation beserta skema routing multiradio multihop, load balancing dan QoS dapat menjadi acuan algoritma untuk jaminan high availability layanan dalam jaringan wirelessmesh. Framework interoperasi antar provider dapat digunakan dalam sistem berbasis cloud yang lebih luas.

Upaya pembenahan teknologi informasi di pedesan, tidak semata tertumpu pada ketersediaan teknologi itu sendiri, tetapi lebih kepada political will oleh pemuka masyarakat dan pemerintah, hal ini disampaikan oleh Agus Pramusinto dan
M. Syahbudin Latief [05], hasil penelitian menunjukkan bahwa peran aktor di luar birokrasi pemerintah desa masih sangat terbatas. Partai politik yang seharusnya bisa menjalankan peran sebagai intermediary agent dalam mewadahi artikulasi kepentingan publik maupun mengontrol dan mengawasi jalannya pemerintahan desa, tidak ditemukan di Desa Wedomartani. Tokoh dari kalangan agama maupun dari masyarakat lebih menonjol. Perubahan politik di tingkat makro mampu menciptakan transformasi di tingkat desa.

Perlu upaya kuat dari pemerintah agar implementasi teknologi informasi di pedesan dapat berjalan dengan baik. Merujuk dari penelitian S. Bayu Wahyono [08], menyampaikan bahwa konsep pengelolaan dan pengembangan Desa Informasi perlu mempertimbangkan asumsi diterminisme sosial yang memiliki karakter bottom-up kemudian dilaksanakan secara konsisten. Desa yang ditunjuk haruslah menyampaikan komitmen untuk menjadikan dirinya sebagai desa informasi. Upaya peningkatan kemampuan aparatur desa harus dilakukan secara masif dan berkesinambungan. Pelatihan tidak akan mencapai target optimal, walaupun demikian ada peningkatan nyata, sebagaimana dikemukakan oleh Hariyanto dan Nuryani Tri Rahayu [04], bahwa hasil rerata pengetahuan dan kemampuan awal peserta dalam mengoperasikan program komputer sebesar 13,78 (39,37\%) dari target materi pelatihan, sedang pengetahuan dan kemampuan akhir setelah pelatihan adalah sebesar 26,44 $(75,54 \%)$ dari target materi pelatihan. Rerata peserta mengalami progres pengetahuan dan kemampuan sebesar 12,67 $(36,2 \%)$.

Perlu di sadari oleh semua pihak bahwa penerapan teknologi informasi akan meningkatkan kemampuan aparatur desa dalam memberikan layanan optimal terhadap masyarakat. Sebagaimana dikemukakan oleh Eko Didik Widianto [03], mengemukakan bahwa sistem cloud computing untuk $e$ goverment bersifat unik, karena mempunyai tipe pegelaran sebagai cloud komunitas. Ada tiga aktor penting anggota komunitas, pengguna cloud, dan pengguna aplikasi. Cloud komunitas bertujuan untuk meniadakan kontrol vendor cloud. Penelitian ini masih perlu dilakukan untuk menghantarkan layanan dan aplikasi e-Government dengan use case berbasis komunitas di atas sistem cloud computing berjalan di atas open source.

Pengamatan terhadap perkembangan e-government di seluruh dunia menunjukkan bahwa aplikasi untuk layanan masyarakat lebih berpengaruh pada negara berkembang, namun tingkat kegagalannya cukup konsisten dalam akseptabilitas dan keberlangsungannya sebagai akibat kekurang-siapan organisasi pemerintahan untuk menerima perubahan serta faktor lain yang sejak semula tidak mendukung keberlangsungan layanan berbasis online. Pengembangan konsep sistem e-government masyarakat berbasis ICT yang mengutamakan efektifitas, akseptabilitas dan keberlangsungan dari penerapan sistem secara nyata masih perlu dipikirkan dengan aplikasi yang sederhana. Beberapa Kegiatan yang Dilakukan Penggunaan e-desa sangat luas dan mengalami perkembangan yang sangat pesat. Hal ini dapat diamati dari sejumlah besar publikasi ilmiah dalam cloud computing, e-desa, dan bidang-bidang terkait lainnya, yang 
dipresentasikan dalam sejumlah banyak pertemuan ilmiah dan/atau dimuat pada berbagai majalah atau proceedings.

Beberapa kegiatan yang saat ini sedang dan akan dilakukan adalah sebagai berikut: (1) sistem tele-administrasi untuk aplikasi dalam bidang pelayanan izin usaha; (2) sistem teleadministrasi untuk aplikasi dalam bidang surat keterangan; (3) penggunaan biometrika sidik jari dalam pencatatan dan identifikasi data masyarakat (untuk desa dengan jumlah masyarakat per hari di atas 100 orang); (4) pengembangan sistem elektronik office untuk desa; (5) sistem e-desa bergerak dengan multi communication links untuk masing-masing RW; (6) sistem tele-administrasi berbasis ICT untuk pengelolaan kejadian luar biasa (wabah); (7) sistem tele-administrasi berbasis ICT untuk pengelolaan masalah pelayanan administrasi bagi masyarakat .

\section{METODE PENELITIAN}

Pada penelitian ini akan dikembangkan sistem adminstrasi pelayanan administrasi online berbasiskan open source dengan pendekatan cloud computing, sehingga dapat digunakan untuk melakukan pendataan masyarakat, izin usaha, rekomendasi, dan penanganan administrasi berhubungan dengan masyarakat di desa dengan biaya yang relative terjangkau. Hal-hal yang dilakukan dalam penelitian ini adalah sebagai berikut: studi literatur yang berkaitan dengan teknologi cloud computing, survei dan pengumpulan data perancangan infrasruktur teknologi informasi yang dapat diterapkan pada pelayanan administrasi masyarakat secara online, analisis data hasil survei terhadap kondisi nyata di beberapa pusat layanan masyarakat khususnya RT dan RW di Desa Tarai Bangun, selanjutnya membuat model palayanan administrasi masyarakat online dari desa seperti janji bertemu Kepala Desa, pembuatan rekomendasi ke Kecamatan serta izin usaha secara online. Kemudian dibuat sistem aplikasi pelayanan administrasi kepada masyarakat online di desa. Di samping itu dalam tahap ini juga akan dikembangkan sistem secara modul untuk lebih memudahkan pengambangan aplikasi lebih lanjut dan memudahkan implementasinya di tempat yang berbeda. Langkah-langkah yang dilakukan dalam penelitian ini adalah:

1. Studi literatur dan pencarian data serta informasi di internet hal ini dilakukan untuk mendapatkan informasi terkini mengenai perkembangan metode dan model pelayanan administrasi secara online di desa dan kecamatan;

2. Pengumpulan data dan survei lapangan - kegiatan ini dilakukan dengan dua cara yaitu survei langsung terhadap desa di wilayah Kabupaten Kampar dan penyebaran kuisioner terhadap masyarakat untuk mendapatkan data metode kondisi layanan dan tingkat kualitas layanan dari suatu pelayanan administrasi sehingga diperoleh gambaran kondisi di lapangan;

3. Analisis data dan pemodelan sistem - dilakukan untuk menganalisis data yang telah terkumpul dengan menggunakan metode statistik untuk mendapatkan parameter-parameter pemodelan sistem, baik yang dikembangkan secara terstruktur ataupun yang dikembangkan dengan metode yang berorientasi objek;

4. Formulasi model dan perancangan sistem dilakukan dengan untuk mendapatkan kebutuhan user dan kebutuhan system secara functional dan non functional serta design system, dalam hal ini akan dirumuskan keterkaitan antara studi literatur dan konsisi lapangan sehingga diperoleh model yang cukup valid;

5. Implemantasi sistem, dimaksudkan untuk membuat prototype dari model system yang telah dibuat sehingga diperolah aplikasi-aplikasi layanan administrasi secara online yang dikembangkan secara modular;

6. Testing dan evaluasi sistem - pengujian dilakukan terhadap system aplikasi dan model yang dikembangkan dengan data real untuk memvalidasi model.

\section{Tahap Pertama: Pengembangan Model Layanan Desa Online}

Pada tahap ini akan dilakukan pengembangan model layanan desa secara online yang meliputi pengembangan database pelaporan dan koordinasi terhadap data masyarakat, data penduduk, data sumber daya dan data operasional desa yang dikemas dalam database berbasis web dengan pendekatan open source programming. Dalam sistem ini dapat digunakan untuk membuat laporan periodik dari layanan desa sehingga setiap layanan desa pada suatu RW atau RT dapat dimonitor oleh aparatur desa ataupun oleh Kecamatan. Dalam tahapan ini juga akan dikembangkan strategi infrastruktur teknologi informasi yang tepat untuk dapat melakukan pelayanan administrasi kepada masyarakat secara online di desa. Pengembangan strategi teknologi informasi tersebut menggunakan pendekatan cloud computing dengan bernasiskan open source. Dengan konsep tersebut diharapkan dapat digunakan untuk melokalisir adanya ketidak puasan oleh masyarakat dalam layanan, karena prosesnya dapat diketahui secara lebih dini, sehingga setiap kebutuhan layanan administrasi oleh masyarakat dapat ditangani secara lebih efisien.

\section{Tahap Kedua: Pengembangan Model Pelaporan Keuangan Online}

Pada tahap ini akan dikembangkan model sistem pelaporan keuangan secara online dengan memberlakukan konsep pencatatan elektronik dan mobile computing untuk dapat melakukan pembelajaran keuangan kepada setiap lapisan masyarakat dengan tingkat informasi yang sama baik ke pusat ataupun daerah. Dengan konsep ini juga dapat memberikan kemudahan terhadap desa yang memiliki keterbatasan kemampuan pengelolaan keuangan, karena ketersediaan tenaga pengelola dapat diwakilioleh suatu sistem yang dapat memberikan solusi pencatatan keuangan pada aparatur desa. Untuk memfokuskan penelitian pada tahap ini akan dikembangkan standar sistem akuntansi pemerintahan. Dalam keuangan, di awali dengan proses perencanaan dan penganggaran, dapat dijelaskan dalam gambar 1 berikut: 


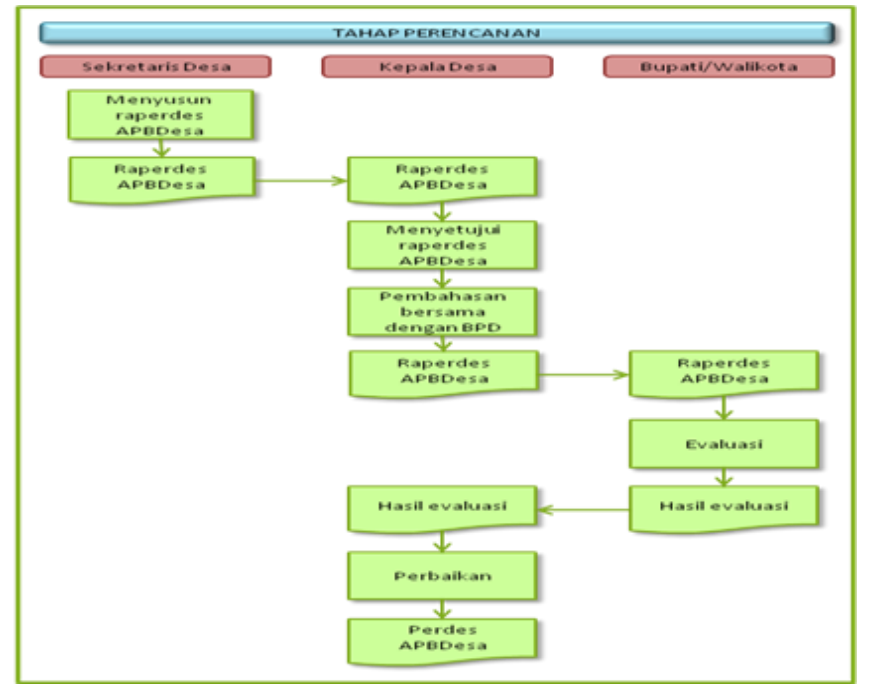

Gambar 1. Proses penganggaran

Organisasi pengelolaan keuangan desa dapat digambarkan dalam grafik berikut ini:

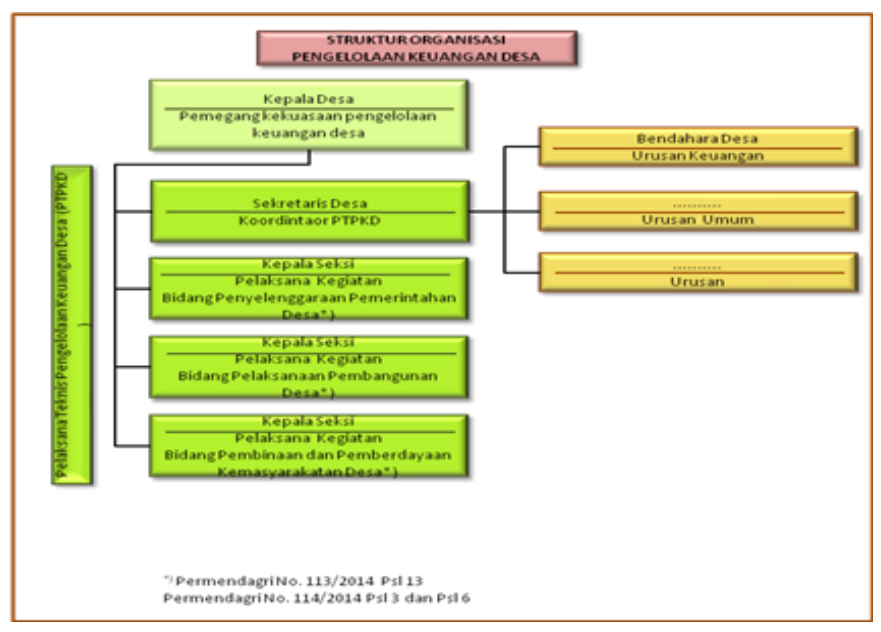

Gambar 2. Organisasi pengelolah keuangan

\section{Tahap Ketiga: Pengembangan Model Konsultasi Administrasi Secara Online}

Pada tahap ini akan dilakukan pembuatan sistem yang dapat melakukan konsultasi masalah secara online atau jarak jauh serta sistem yang dapat melakukan monitoring terhadap data masyarakat secara real time sepanjang waktu sehingga dapat mengetahui konsidi perkembangan masyarakat secara lebih akurat. Beberapa metode yang digunakan dalam mengembangkan model konsultasi administrasi adalah dengan pendekatan humanis,sehingga masyarakat merasa betah dan terbuka mengemukakan masalah yang di alami. Hasil yang diharapkan dalam tahap ini adalah adanya suatu sistem yang dapat memantau masyarakat secara online dengan menggunakan teknologi cloud computing. Selain itu juga dapat menciptakan suasana nyaman bagi masyarakat dalam melaksanakan administrasi desa.

\section{HASIL DAN PEMBAHASAN}

Pemanfaatan SaaS (Software as a Service) dipilih dalam pengembangan model aplikasi administrasi pelayanan masyarakat di desa berbasiskan open source karena teknologi ini memiliki karakteristik layanan yang memberikan manfaat antara lain dalam efisiensi biaya operasional terutama pada pelayanan aparatur desa. Dengan komputasi awan aparatur desa tidak perlu melakukan pengembangan, pembelian, pemeliharaan dan pengamanan perangkat lunak dan keras serta sistem operasi karena sudah dilakukan secara virtual oleh penyedia layanan tersebut, termasuk proses keterkiniannya. Beberapa manfaat yang diperoleh antara lain (1) Penghematan biaya, penggunaan teknologi ini menghemat biaya karena menggunakan anggaran yang rendah untuk sumber daya dari desa dan juga membantu dalam menekan biaya operasi yang dikeluarkan oleh desa dalam rangka meningkatkan reliability dan kritikan sistem yang dibangun. (2) Peningkatan kapasitas penyimpanan, desa yang menggunakan teknologi ini dapat menyimpan data lebih banyak dibandingkan pada komputer pribadi. (3) Mudah diotomatisasi seorang pengembang tidak perlu khawatir terhadap perangkat lunak atau aplikasi pelayanan administrasi desa agar tetap up-to-date. (4) Fleksibel, teknologi ini menawarkan lebih banyak fleksibilitas, contohnya dalam hal virtualisasi, dari metode komputasi sebelumnya dan dengan mudah dapat berorientasi pada profit dan perkembangan yang cepat berubah. (5) Mobilitas yang lebih, desa yang mempunyai pegawai/pengguna dapat mengakses informasi di manapun berada. Cloud dapat membuat manejemen dan operasional lebih mudah karena masyarakat atau desa terkoneksi dalam satu cloud sehingga dapat dengan mudah untuk memonitor dan mengaturnya. (6) Mengubah titik fokus, desa tidak perlu lagi mengkhawatirkan server yang harus di-update dan isu komputasi lainnya, sehingga dapat fokus pada hal lain. Pengembangan model aplikasi administrasi pelayanan di RT dan RW dengan cloud computing berbasiskan open source dapat dilihat pada gambar 3 berikut ini.

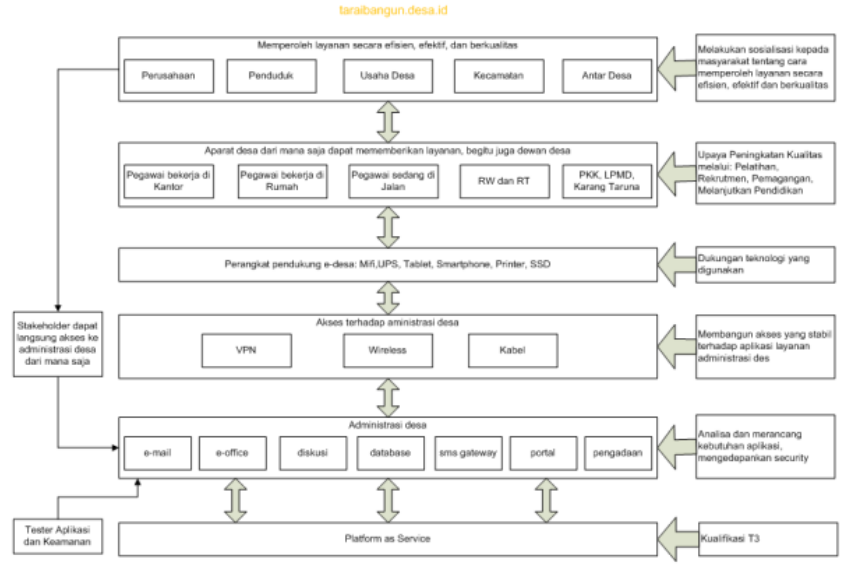

Gambar 3. Pengembangan Model 
Model aplikasi pada penelitian ini merupakan aplikasi sistem informasi yang digunakan untuk pelayanan administrasi desa diharapkan terutama dalam lingkup yang luas dan komprehensif. Dikembangkan berbasis web dengan memanfaatkan teknologi cloud computing serta arsitektur pengembangan yang bersifat modular dan dinamis. Model aplikasi ini juga memadukan keunggulan aplikasi berpola open-source dengan desain sistem yang fleksibel untuk kebutuhan implementasi dan pengembangan, serta mendukung mobile device untuk meningkatkan kualitas pelayanan masyarakat.Struktur jaringan yang berbasis web memungkinkan untuk online tidak hanya antar bagian tetapi juga antar instansi dan dapat diakses kapan saja, di mana saja, serta menggunakan perangkat bergerak. Protokol komunikasi yang tersedia dirancang dengan tingkat keamanan yang tinggi untuk memastikan tingkat kerahasiaan data. Setiap masyarakat selalu mengharapkan pelayanan yang terbaik dan profesional dari seorang ahli, dan tentunya diharapkan pula dengan harga yang terjangkau untuk segala lapisan masyarakat. Pengembangan model aplikasi juga disesuaikan dengan fungsi proses bisnis dan proses administrasi desa yang ada di seluruh Indonesia. Hal ini dapat menyederhanakan proses kerja dan menghindari overhead akibat fitur-fitur yang sebenarnya tidak diperlukan. Setiap model juga diharapkan dapat diintegrasikan untuk mengoptimalkan efisiensi dan telah coba disesuaikan dengan sistem pelayanan administrasi desa.

\section{KESIMPULAN}

Data dalam penelitian ini disusun setiap kali seorang masyarakat memperoleh layanan administrasi dari sebuah bagian di desa, misalnya pengurusan izin usaha, surat keterangan berdomisili, surat pengantar ke Kantor Camat; atau berdasarkan hasil kegiatan administratif, misalnya untuk memperoleh bantuan beasiswa Bidik Misi. Dalam sistem layanan administrasi desa yang telah ada secara umum, masyarakat dan aparatur desa berhadapan dengan data melalui aplikasi yang tersedia untuk setiap bagian tersebut secara terpisah. Pertukaran data antar bagian, bila diperlukan, masih berdasarkan catatan kertas yang diantar dari satu bagian ke bagian lain diharapkan sudah tidak terjadi lagi dengan adanya penelitian ini Arsitektur sistem administrasi pelayanan masyarakat yang terstruktur dapat dikelola oleh sistem ini dan memungkinkan data digunakan bersama dalam sistem. Komponen utama dari sistem ini adalah: (1) komponen administratif, (2) komponen Badan Permusyawaratan Desa, (3) komponen Sekretaris Desa, (4) komponen Ketua RW, serta (5) Pelaksana Teknis.

\section{DAFTAR PUSTAKA}

[1] Eko Didik Widianto, Menuju Sistem e-Government Terpadu dan Handal Berbasis Cloud Computing, Jurnal Sistem Komputer Vol. 1 No. 1 Tahun 2011, ISSN: 2087-4685

[2] Ni Ketut Bagiastuti, Implementasi Eksternal Otonomi Desa Adat, Soshum Jurnal Sosial Dan Humaniora, Vol. 2, No. 3, Nopember 2012 165

[3] Siti Maimunah., Rudianto, Pelayanan Teknologi Informasi Dan Komunikasi Untuk Pengembangan Desa, E-Indonesia Initiative 2008 (Eii2008) Konferensi Dan Temu Nasional Teknologi Informasi Dan Komunikasi Untuk Indonesia, 21-23 Mei 2008, Jakarta

[4] Hariyanto., Nuryani Tri Rahayu, Ibm Sistem Administrasi Desa Berbasis Komputer, Seminar Hasil Penelitian dan Pengabdian kepada Masyarakat Tahun 2011, LPPM Univet Bantara Sukoharjo, ISBN 978602-99172-5-3

[5] Agus Pramusinto, M. Syahbudin Latief, Dinamika Good Governance di Tingkat Desa: Kajian Praktik di Wedomartani Sleman, Volume 11, Nomor 1, Januari 2011, halaman 1-13, JURNAL ILMU ADMINISTRASI NEGARA, 2011

[6] I Putu Agus Eka Pratama, Smart City beserta Cloud Computing dan Teknologi Pendukung, Informatika Bandung, Bandung, 2014

[7] Eko Didik Widianto, Studi Cloud Computing untuk Layanan HighAvailability di Jaringan Telekomunikasi Pedesaan, Seminar Nasional Teknologi Informasi, 2009

[8] S. Bayu Wahyono, Optimalisasi Program Desa Informasi Melalui Penguatan Kelembagaan, Jurnal Penelitian IPTEK-KOM, Volume 13, No. 2, Desember 2011

[9] http://www.bps.go.id/index.php/publikasi/1024 